\title{
Biocatalytic Reduction of Formaldehyde to Methanol: Effect of pH on Enzyme Immobilization and Reactive Membrane Performance
}

\author{
Norhayati Abdul Rahman'1, Fauziah Marpani ${ }^{2, *}$, Nur Hidayati Othman', \\ Nur Hashimah Alias ${ }^{1}$, Junaidah Jai ${ }^{1}$, Nik Raikhan Nik Him ${ }^{1}$ \\ ${ }^{1}$ Faculty of Chemical Engineering, Universiti Teknologi MARA, 40450 Shah Alam, Selangor Darul Ehsan, \\ Malaysia. \\ 2Integrated Separation Technology Research Group (i-STRonG), Faculty of Chemical Engineering, Universiti \\ Teknologi MARA, 40450 Shah Alam, Selangor Darul Ehsan, Malaysia.
}

Received: $16^{\text {th }}$ March 2021; Revised: $4^{\text {th }}$ May 2021; Accepted: $5^{\text {th }}$ May 2021

Available online: 10th May 2021; Published regularly: September 2021

\section{Abstract}

Thermodynamic stabled $\mathrm{CO}_{2}$ molecules can be biocatalytically reduced to methanol via three cascade dehydrogenases (formate, formaldehyde and alcohol) with the aid of cofactor as the electron donor. In this study, Alcohol dehydrogenase (EC 1.1.1.1), the third step of the cascade enzymatic reaction which catalyzed formaldehyde $(\mathrm{CHOH})$ to methanol $\left(\mathrm{CH}_{3} \mathrm{OH}\right)$ will be immobilized in an ultrafiltration membrane. The enzyme will be immobilized in the support layer of a poly(ether)sulfone (PES) membrane via a technique called fouling induced enzyme immobilization. The objective of this study is to evaluate the effect of varying $\mathrm{pH}$ (acid (pH 5), neutral $(\mathrm{pH} 7)$ and alkaline $(\mathrm{pH}$ 9)) of the feed solution during immobilization process of $\mathrm{ADH}$ in the membrane in terms of permeate flux, observed rejection, enzyme loading and fouling mechanism. The experiment was conducted in a pressure driven, dead-end stirred filtration cell. Reaction conversion and biocatalytic productivity will be also evaluated. The results showed that permeate flux for acid solution were the lowest during immobilization. High concentration polarization and fouling resistance cause lower observed rejection for $\mathrm{pH} 7$ and 9. Enzyme loading for $\mathrm{pH} 5$ give $73.8 \%$ loading rate which is the highest compared to $62.4 \%$ at $\mathrm{pH} 7$ and $70.1 \%$ at $\mathrm{pH} 9$. Meanwhile, the conversion rate during the reaction shows that reaction on fouled membrane showed more than $90 \%$ conversion for $\mathrm{pH} 5$ and 7 . The fouling model predicted that irreversible fouling occurs during enzyme immobilization at $\mathrm{pH} 7$ with standard blocking mechanism while reversible fouling occurs at $\mathrm{pH} 5$ and 9 with intermediate and complete blocking, respectively.

Copyright (C) 2021 by Authors, Published by BCREC Group. This is an open access article under the CC BY-SA License (https://creativecommons.org/licenses/by-sa/4.0).

Keywords: Enzyme Membrane Reactor; Enzyme Immobilization; Membrane Fouling; Biocatalysis; $\mathrm{CO}_{2} \mathrm{Reduction}$ Reactive Separation

How to Cite: N.A. Rahman, F. Marpani, N.H. Othman, N.H. Alias, J. Jai, N.R.N. Him (2021). Biocatalytic Reduction of Formaldehyde to Methanol: Effect of $\mathrm{pH}$ on Enzyme Immobilization and Reactive Membrane Performance. Bulletin of Chemical Reaction Engineering \& Catalysis, 16(3), 472-480 (doi:10.9767/bcrec.16.3.10568.472-480)

Permalink/DOI: https://doi.org/10.9767/bcrec.16.3.10568.472-480

\section{Introduction}

The global emission of carbon dioxide $\left(\mathrm{CO}_{2}\right)$ was recommended by Intergovernmental Panel

\footnotetext{
* Corresponding Author.

Email: fauziah176@uitm.edu.my (F. Marpani)

Telp: +60-3-55436510, Fax: +60-3-55436300
}

on Climate Change (IPCC) to be reduced by 50 $80 \%$ based on 1990 levels by the year 2050 [1]. Industrial activities contribute $30 \%$ of the total anthropogenic emission of $\mathrm{CO}_{2}$ [2]. Emission of $\mathrm{CO}_{2}$ are mainly from the combustion of fossil fuel and discharges from thermoelectric power plant, steel mills, refineries, and cement plant [3]. The concentration of atmospheric $\mathrm{CO}_{2}$ is ris- 
ing around $400 \mathrm{ppm}$ due to massive global emissions [4]. Based on the research by Global Carbon Project, an international research consortium, presented their findings at the United Nations climate talks in Bonn, Germany shows that global $\mathrm{CO}_{2}$ emissions reach 41 billion tones in 2017 [5]. Some parties have decided to reduce $\mathrm{CO}_{2}$ emissions during international climate negotiation under United Nations Framework convectional on Climate Change (UNFCC). The aim of the framework calls for limiting global warming to a rise of $1.5-2{ }^{\circ} \mathrm{C}$ [6]. Thus, critical measures must be made to reduce atmospheric $\mathrm{CO}_{2}$ levels, such as carbon capture and storage [7-9], direct emission reduction of $\mathrm{CO}_{2}$ by development of clean and sustainable energy resources replacing nonrenewable fossil fuels and converting $\mathrm{CO}_{2}$ into useful chemicals $[10,11]$.

One way to reduce $\mathrm{CO}_{2}$ emissions to the atmosphere is by converting $\mathrm{CO}_{2}$ to valuable product such as methanol. This attractive strategy developing measure for reducing greenhouse gas emission by utilization of $\mathrm{CO}_{2}$ as feedstock for producing chemicals and fuels. These products can be beneficial product for industries at the same time give a sustainable options of $\mathrm{CO}_{2}$ conversion with zero and negative emission of greenhouse gas [12]. The main conversion step of $\mathrm{CO}_{2}$ involving biological processes is the conversion using enzymatic step with the Calvin cycle for $\mathrm{CO}_{2}$ conversion in nature. However, in nature, sequential enzymatic reduction of $\mathrm{CO}_{2}$ to methanol does not occur. Enzymatic biocatalytic process for sequential reduction of $\mathrm{CO}_{2}$ to methanol had been discovered by Obert and Dave where methanol is produced from combination of formate dehydrogenase (FDH), Formaldehyde dehydrogenase and Alcohol Dehydrogenase. In this process, reduced nicotinamide adenine dinucleotide $(\mathrm{NADH})$ was used as the terminal electron do-

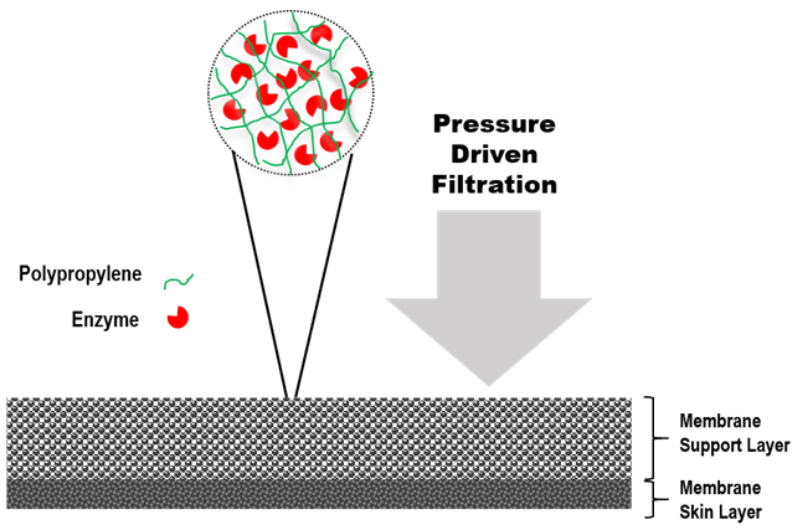

Scheme 1. Membrane orientation in Amicon stirred cell, dead end filtration adapted from [14]. nor for the enzymatic reaction [13]. The $\mathrm{CO}_{2}$ is thermodynamically stabled molecule. Hence, to be able to reduce $\mathrm{CO}_{2}$ by this biocatalytic process is a good achievement in science because enzymatic reaction is sustainable.

In this study, Alcohol Dehydrogenase (ADH) was immobilized in the support layer of poly(ether)sulfone (PES) ultrafiltration membrane. ADH catalyzed the conversion of formaldehyde to methanol with the simultaneous cofactor oxidation of NADH to $\mathrm{NAD}^{+}$was used as the enzyme model. The reaction is the final phase of three (3) cascades enzyme catalysis of $\mathrm{CO}_{2}$ to $\mathrm{CH}_{3} \mathrm{OH}$. $\mathrm{ADH}$ immobilization in/on membrane will inevitably foul the membrane. Hence, it is hypothesized that controlled fouling could be applied to immobilize enzyme efficiently. In this study, controlled fouling of membrane can be done by manipulating the $\mathrm{pH}$ of buffer solutions during enzyme immobilization. The objective of this study is to evaluate the fouling mechanisms during fouling-induced enzyme immobilization on the support of commercial PES ultrafiltration membrane at different $\mathrm{pH}$ of 5,7 , and 9. Constant pressure fouling model from Hermia was fitted with experimental data to elucidate the enzyme distribution on the support of the membrane. The performance of the enzymatic membrane reactor in terms of membrane permeability before and after enzyme immobilization and during reaction, enzyme loading at different $\mathrm{pH}$ and the percentage conversion will be also evaluated.

\section{Materials and Methods}

\subsection{Chemicals and Membrane Properties}

All chemicals used in the experiments were purchased from Sigma-Aldrich (St. Louis, MO, USA) which includes alcohol dehydrogenase from Saccharomyces cerevisiae, $\beta$-nicotiamide dinudeotide (NADH), formaldehyde $(37 \% \mathrm{w} / \mathrm{w})$, sodium acetate trihydrate, acetic acid, dipotassium phosphate $\left(\mathrm{K}_{2} \mathrm{HPO}_{4}\right)$, monopotassium phosphate $\left(\mathrm{KH}_{2} \mathrm{PO}_{4}\right)$, Trizma-base and hydrochloric acid. Enzyme and substrate solution were prepared with different buffer solution, $0.1 \mathrm{M}$ Acetate buffer at $\mathrm{pH} 5,0.1 \mathrm{M}$ tris $-\mathrm{HCl}$ at pH 7 and 9. The molecular weight of formaldehyde, NADH and $\mathrm{ADH}$ were $0.03 \mathrm{kDa}, 0.7$ and $141 \mathrm{kDa}$, respectively. The flat-sheet ultrafiltration membrane is used is made of poly(ether)sulfone (PES) (skin) and polypropylene (support), $30 \mathrm{kDa}$ molecular weight cut off, with $13.4 \mathrm{~cm}^{2}$ of effective area (Synder, CA, USA). Schematic diagram of the experimental setup is shown in Scheme 1. 


\subsection{Experimental Set-up and Procedure}

Membrane was soaked in ultrapure water for two minutes and followed by $50 \%$ ethanol solution for two minutes to remove the protective layer of the membrane based on manufacturer's instructions. The membrane support layer will be facing feed. An extra polypropylene support will be placed below the skin layer to avoid compression. The ultrafiltration filtration experiments were carried out in a $50 \mathrm{~mL}$ dead-end stirred cell (Amicon 8050, Milipore, USA) with fixed stirring speed of $100 \mathrm{rpm}$. Nitrogen gas pressure of 1 bar will be purged in to measure water permeability of membrane. Water permeability will be measured by filtration of pure water continuously for 10 minutes. A pressure of 2 bar was set during enzyme immobilization and reaction. Permeate was collected in a $10 \mathrm{~mL}$ cylinder tube to monitor the permeate flux. All the experiments were performed at room temperature $\left(25^{\circ} \mathrm{C}\right)$.

\subsection{Immobilization of Alcohol Dehydrogenase}

Different $\mathrm{pH}$ buffer solutions ( $\mathrm{pH} 5,7$, and 9) were used to carried out enzyme immobilization. $30 \mathrm{~mL}$ enzyme solution $(0.1 \mathrm{~g} / \mathrm{L})$ was poured into the cell with pressure of 2 bar. The permeate was collected in a precise cylinder for analysis. The fouled membrane fitted in the cell was rinsed 3 times at the end of filtration with $5 \mathrm{ml}$ of buffer each time without applying pressure. The retentate and rinsing residual were collected. Finally, the fouled membrane was filtered with buffer at $\mathrm{pH} 7$ at 1 bar and permeate was collected for mass balance analysis. $\mathrm{ADH}$ concentration was evaluated using Bradford protein assay and absorption value was measured at $595 \mathrm{~nm}$ using UV-VIS spectrophotometer (Perkin Elmer, Germany).

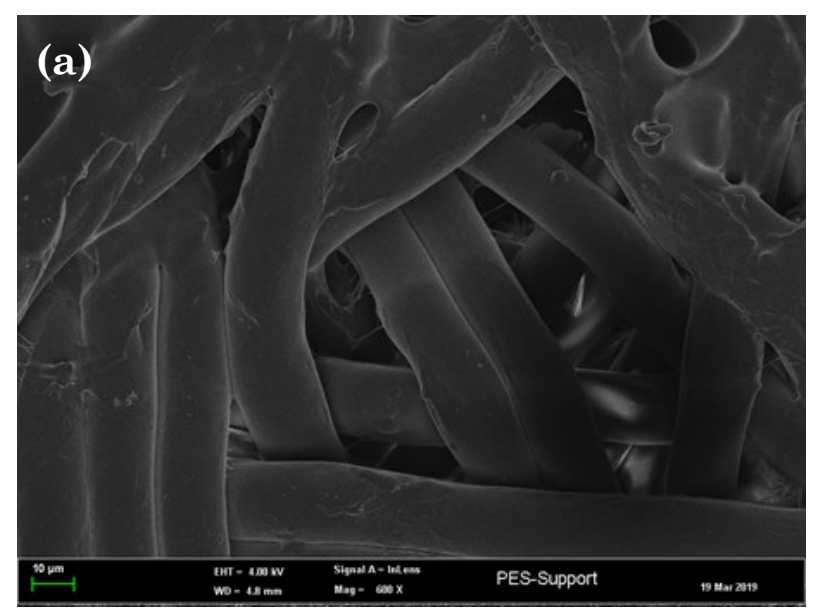

\subsection{Enzymatic Reaction}

The enzyme reaction of $30 \mathrm{~mL}$ of substrate mixture $(134 \mu \mathrm{M} \mathrm{HCOH}+100 \mu \mathrm{M} \mathrm{NADH})$ at $\mathrm{pH} 7$ was fed into the Amicon stirred cell which was prior immobilized with ADH. Permeates were collected for every $4 \mathrm{ml}$ were collected and analyzed immediately. Absorbance at $340 \mathrm{~nm}$ set to monitor NADH concentration during reaction.

\subsection{Calculated Parameters}

Observed rejection of enzyme was calculated as:

$R_{\text {obs }}(\%)=\left(1-\frac{C_{p}}{C_{o}}\right) \times 100$

where, $C_{p}$ (concentration of enzyme in permeate) and $C_{o}$ (concentration of enzyme in the feed) during immobilization. The amount of enzyme immobilized can be estimated from the following equation:

$$
m_{i}=m_{t}-C_{p} V_{p}-C_{r} V_{r}-C_{w} V_{w}
$$

The enzyme immobilization efficiency of in the membrane is expressed as loading percentage:

$$
\text { Enzymeloading }(\%)=\frac{m_{i}}{m_{t}} \times 100
$$

where $m_{i}$ is amount of immobilized enzyme, $m_{t}$ is the amount of enzyme in the feed, $C_{p}, C_{r}$, and $C_{w}$ are the concentration of enzyme in the permeate, retentate and rinsing residual, and pressure-driven washing, respectively. $V_{p}, V_{r}$, and $V_{w}$ are the volume obtained from the permeate, retentate and rinsing residual, and pressure-driven washing, respectively.

Analysis of the biocatalytic conversion is calculated as percent oxidation of NADH to $\mathrm{NAD}^{+}$:

$$
\text { Biocatalytic conversion }(\%)=\frac{C_{i, N A D H}-C_{p, N A D H}}{C_{i, N A D H}} \times 100
$$

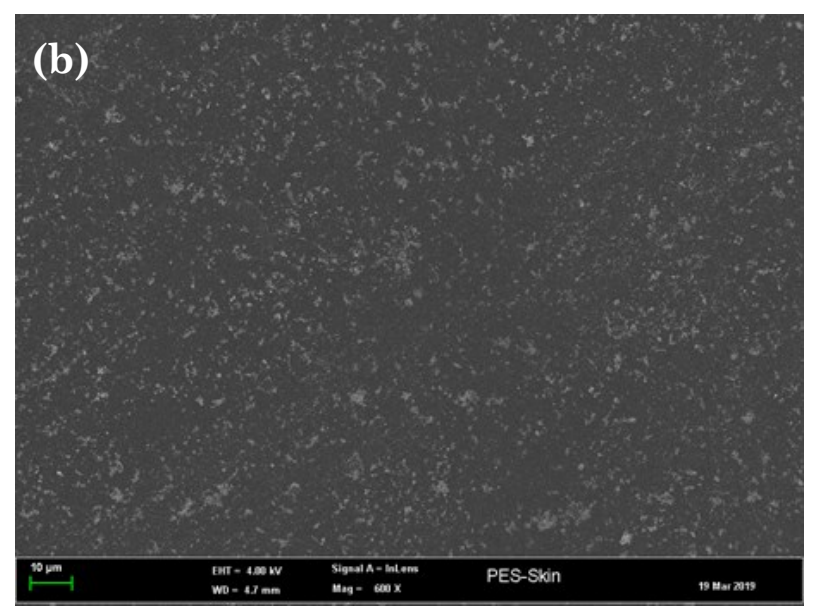

Figure 1. SEM images of (a) support layer (b) skin layer of PES membrane. 
where, $C_{i, N A D H}$ is the initial concentration of $\mathrm{NADH}$ in the feed and $C_{p, N A D H}$ is the concentration of $\mathrm{NADH}$ in the permeate during reaction. The details of filtration blocking model is referred from previous work [14].

\section{Results and Discussion}

\subsection{Membrane Characterization}

Figure 1 shows SEM images of the support and skin layer of PES membrane used in the experiment with the same scale of $10 \mu \mathrm{m}$. The support layer consists of fibrous like structure from polyethylene, making it suitable to immobilize enzyme and potentially minimize mass transfer resistance during biocatalysis. The skin layer molecular weight cut off is $30 \mathrm{kDa}$ and there are no obvious pores can be seen. This condition is expected to retain the enzyme in the support layer and alleviate enzyme leakage during the reaction stage.

Permeate flux during enzyme immobilization at different solution $\mathrm{pH}$ is shown in Figure 2. Pristine PES membrane recorded a water permeability of $91.5 \mathrm{~L} / \mathrm{m}^{2} \cdot \mathrm{h} \cdot \mathrm{bar}$. Membrane permeability decreases with time (cumulative permeate volume). The average membrane permeability is decreasing when the solution $\mathrm{pH}$ is lower (acid). The trend is the same for all solution $\mathrm{pH}$. Figure 3 shows the observed rejections

- pH 5 pH 7 ^ pH9 oPristine Membrane

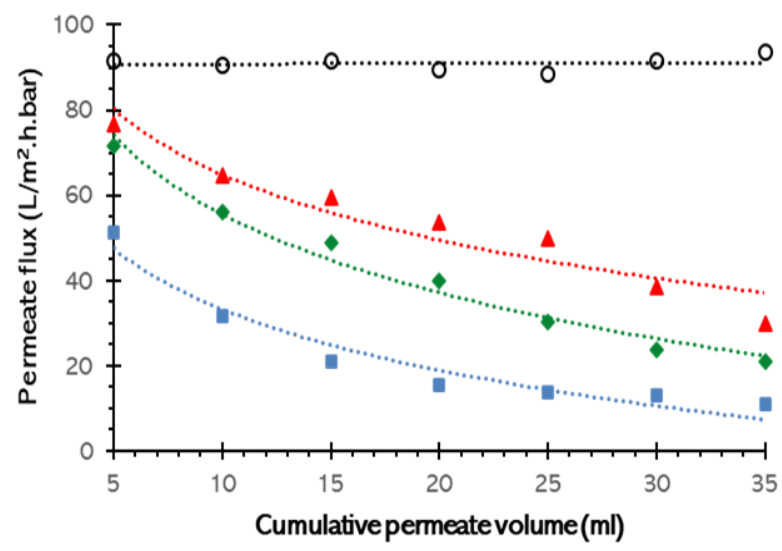

Figure 2. Permeate flux trend during immobilization with different $\mathrm{pH}$. as a function of permeate flux at different $\mathrm{pH}$. Observed rejection on membrane is an index of solutes retainment by the membrane whether the solutes show lower solubility in water or the solutes diffusion occurs at a low pace through the membrane. The index is indicated by $100 \%$ for completely permeable membrane, while $0 \%$ indicates completely impermeable membrane. During earlier filtration process of enzyme, the flux decline is rapid for the first 10 $\mathrm{ml}$ of permeate (Figure 2). At the same time, the membrane is shown to be completely permeable with more than $80 \%$ observed rejection (Figure 3). After some time, the flux decline becoming gradual (Figure 2). At this stage, the membrane become semi-permeable because the observed rejection is at $50 \%$ at the end of filtration process for $\mathrm{pH} 7$ and $60 \%$ for $\mathrm{pH} 9$. The observed rejection is stable above $90 \%$ throughout filtration process at $\mathrm{pH} 5$. The results showed that the membrane was responsive towards different solution $\mathrm{pH}$ with severe flux decline observed at the lowest $\mathrm{pH}(\mathrm{pH} 5)$.

3.2 Effect of $\mathrm{pH}$ on Enzyme Immobilization and Membrane Fouling

The lowest enzyme loading was recorded when the $\mathrm{pH}$ solution was neutral, which was $62.4 \%$ from $3.0 \mathrm{mg}$ in the feed solution (Table

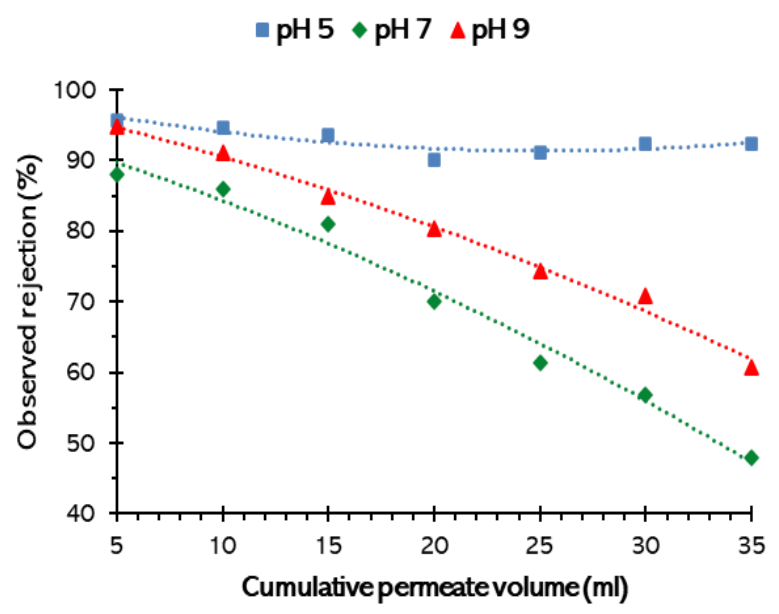

Figure 3. Observed rejection based on immobilization with different $\mathrm{pH}$.

Table 1. Amount of enzyme immobilized in the membrane at different $\mathrm{pH}$.

\begin{tabular}{cccccc}
\hline \multirow{2}{*}{ Solution $\mathrm{pH}$} & \multicolumn{4}{c}{ Amount of enzyme $(\mathrm{mg})$} & $\begin{array}{c}\text { Enzyme loading } \\
\text { (\%) }\end{array}$ \\
\cline { 2 - 5 } & Feed & Permeate & Retentate & Washing Residue & 73.8 \\
5 & 3.0 & 0.151 & 0.312 & 0.323 & 62.4 \\
9 & 3.0 & 0.773 & 0.201 & 0.461 & 70.1 \\
\hline
\end{tabular}


1). The highest enzyme loading was observed at pH 5 with $73.8 \%$. There are two possible mechanisms in which enzyme could anchored on the membrane, which in this case it is regarded as membrane fouling. Fouling occurs either by electrostatic charge and hydrophobic interaction or retention by electrostatic repulsion and steric hindrance $[15,16]$. It could also by synergy of the two mechanisms. It was suggested that at $\mathrm{pH} 5$, the enzyme is anchored on the membrane by electrostatic charge and hydrophobic interaction, while at $\mathrm{pH} \mathrm{9,} \mathrm{enzyme} \mathrm{re-}$ tention by electrostatic repulsion and steric hindrance dominated $[15,17]$.

The degree of membrane fouling can be distinguished during enzyme immobilization at different solution $\mathrm{pH}[18,19]$. The discussion of the effect of different $\mathrm{pH}$ on membrane fouling is closely related to the isoelectric point (pI) [20]. $\mathrm{pI}$ is the $\mathrm{pH}$ of a solution at which the net charge of a protein becomes zero. In other words, the net charge of macromolecular protein is positive if the surrounding $\mathrm{pH}$ is less than the pI, while the net charge is negative if the $\mathrm{pH}$ is more than the $\mathrm{pI}$. As a result, whenever the $\mathrm{pH}$ of the solution differs from $\mathrm{pI}$, the

\section{Standard blocking}

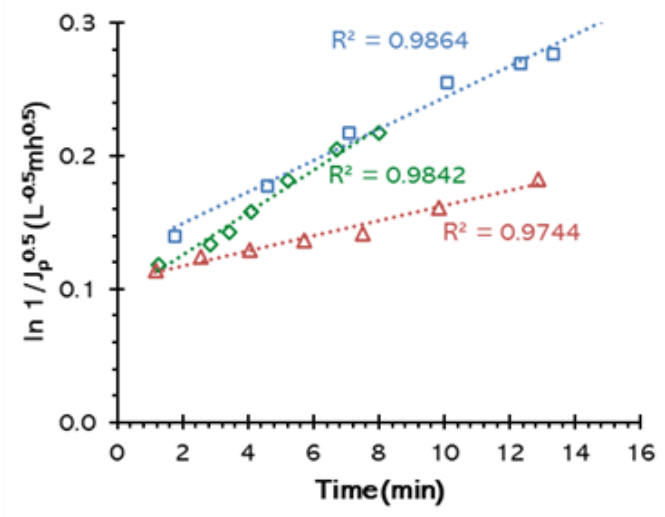

Complete blocking

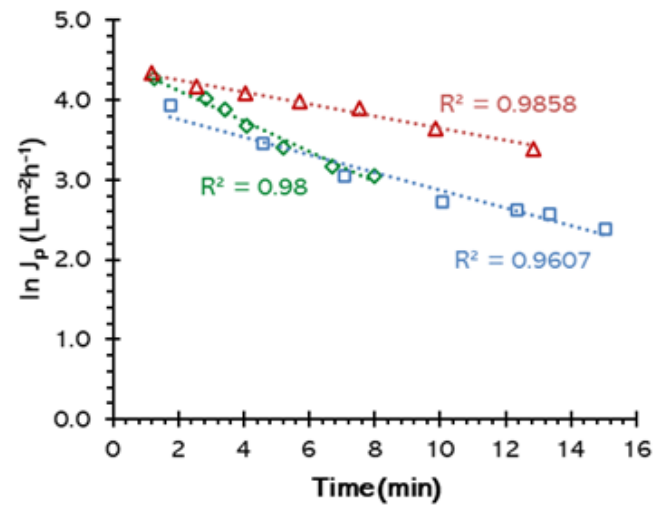

(a)

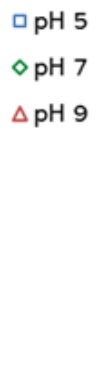

(c)

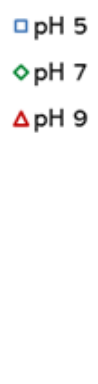

protein surfaces can be either net positive or negative charges. $\mathrm{pI}$ for PES membrane is at $\mathrm{pH}$ range of 4 to 5 while $\mathrm{pI}$ for $\mathrm{ADH}$ enzymes is around $\mathrm{pH} 5.4$ to 5.8 [21]. Generally, when the filtrating solution is acid ( $\mathrm{pH} 5)$, the membrane was almost neutral. At this $\mathrm{pH}$, enzyme is positively charged. Fouling is prominent because there is significant hydrophobic adsorption between enzymes and the membrane [22,23]. This explained the highest loading of enzyme at $73.8 \%$ at $\mathrm{pH} 5$, compared to $\mathrm{pH} 7$ and $\mathrm{pH} 9$.

In this study, fouling mechanism is described by fitting in permeate flux data during enzyme immobilization at different solution $\mathrm{pH}$ into Hermia model. This model is selected considering that it is the most complete model describing dead-end filtration in batch system $[24,25]$. According to this model, there are four major fouling mechanisms, which was described as complete blocking, intermediate blocking, standard blocking, and cake layer formation. Complete blocking is interpreted when the size of ADH enzymes (foulant) is the same with the pore size of the membrane and the foulant deposited on the pores completely blocked the flow passage.

Intermediate blocking

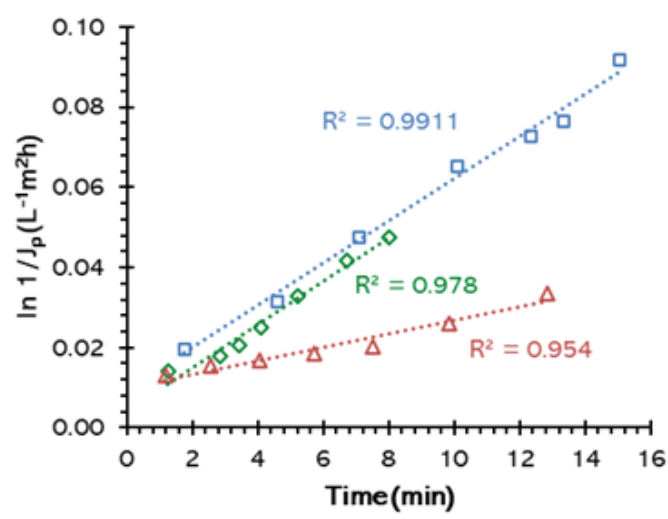

$\square \mathrm{pH} 5$

$\diamond \mathrm{pH} 7$

$\triangle \mathrm{pH} 9$

Cake layer

(d)

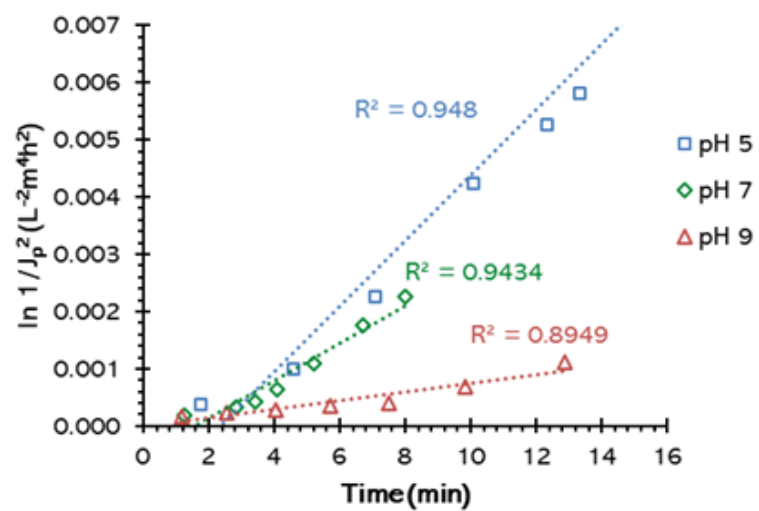

Figure 4. Experimental data fitting into Hermia dead-end filtration model; (a) Standard blocking; (b) Intermediate blocking; (c) Complete blocking and (d) Cake layer. 
This type of fouling mechanism will result in reduced number 'free' pores. In intermediate blocking, a single foulant could form aggregates with other particles and create multi-layers on the membrane surface which subsequently lead to increase in cake thickness. As the foulant deposits on the internal pore surface, it reduces the free pore volume, and this is known as standard blocking. The most severe fouling mechanism is cake layer formation, whereby all the foulants deposited on top of each foulants which previously had blocked the pores. The type of fouling is determined by the highest degree of model fitness $\left(\mathrm{R}^{2}\right)$ when fitting in permeate flux data during enzyme immobilization at different solution $\mathrm{pH}$ (Figure 4) [24].

Intermediate blocking dominates at $\mathrm{pH} 5$ (Figure 5). At this $\mathrm{pH}$, the surface of the membrane obtained positive net charge because the solution $\mathrm{pH}$ is lower than the isoelectric point of the membrane. The feed solution is also positively charged at $\mathrm{pH} 5$. The same charges on the membrane's surface cause the enzyme molecule repelled away from the membrane's surface. Nevertheless, during pressure-driven filtration, the enzyme molecule, will be 'forced' to dock on the surface of the membrane. This allows more enzyme molecules to deposit on the previously accumulated $\mathrm{ADH}$ on the membrane pores. At $\mathrm{pH}$ 9, complete blocking dominates (Figure 5). The membrane surface obtained negative net charge because the solution $\mathrm{pH}$ is higher than the isoelectric point of the membrane. Different charges interaction on the surface of the membrane causing the enzyme molecules attracted on the surface of the membrane and completely blocked the pores. Only $70.1 \%$ is immobilized on the surface of the membrane, there are 'free' pores on the membrane compared to intermediate blocking, and responsible for a higher permeate flux from the rest. At $\mathrm{pH} 7$, standard blocking dominates. For

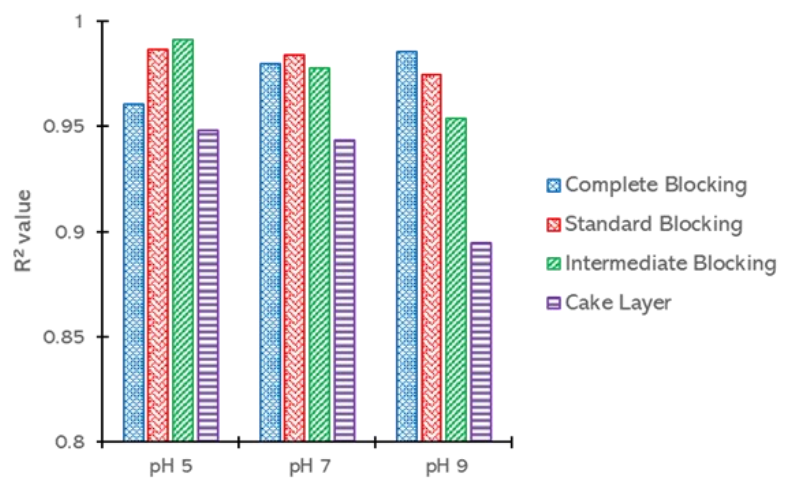

Figure 5. Analysis of $\mathrm{R}^{2}$ value calculated from Hermia's model data fitting. this type of fouling, enzyme molecules adsorbed inside the membrane pores and cause reduction in pore diameter [26].

\subsection{Reactive Membrane Performance}

Enzymatic reaction in converting formaldehyde to methanol was continued after immobilization of membrane at different $\mathrm{pH}$. Figure 6 shows the result of permeate flux during reaction where membrane fouled with $\mathrm{pH} 5$ give the lowest permeate flux with an average of 33 $\mathrm{L} / \mathrm{m}^{2} \cdot \mathrm{h}$ bar. Hence, largest irreversible fouling resistance occur give slowest permeate flux during reaction due to more enzyme docked on the membrane (Figure 5). Irreversible fouling refers to complete, standard and intermediate blocking in Hermia's model [27]. The permeate flux of $\mathrm{pH} 9$ is $62 \mathrm{~L} / \mathrm{m}^{2} \cdot \mathrm{h}$ bar which higher compared to other $\mathrm{pH}$ as the irreversible fouling resistance during immobilization is low (Figure 5). So that, it makes the smooth filtration progress during the enzymatic reaction.

The biocatalytic conversion during enzymatic reaction applied on fouled membrane at $\mathrm{pH} 5$ show the highest conversion rate at an average of $95 \%$, followed by pH 7 at an average of $90 \%$ conversion. At $\mathrm{pH}$ 9, initial conversion was at $90 \%$ and decreases to $80 \%$ at the end of the reaction time. The biocatalytic conversion during enzymatic reaction applied on fouled membrane at $\mathrm{pH} 5$ show the highest conversion rate at an average of $95 \%$, followed by $\mathrm{pH} 7$ at an average of $90 \%$ conversion. Although enzyme loading was quite high at $\mathrm{pH} 9$, initial conversion at $90 \%$ decreases to $80 \%$ at the end of the reaction time (Figure 7). At $\mathrm{pH}$ 9, some enzymes could have been rejected by the membrane via electrostatic repulsion [28]. During the reaction, the $\mathrm{pH}$ of the feed solution is

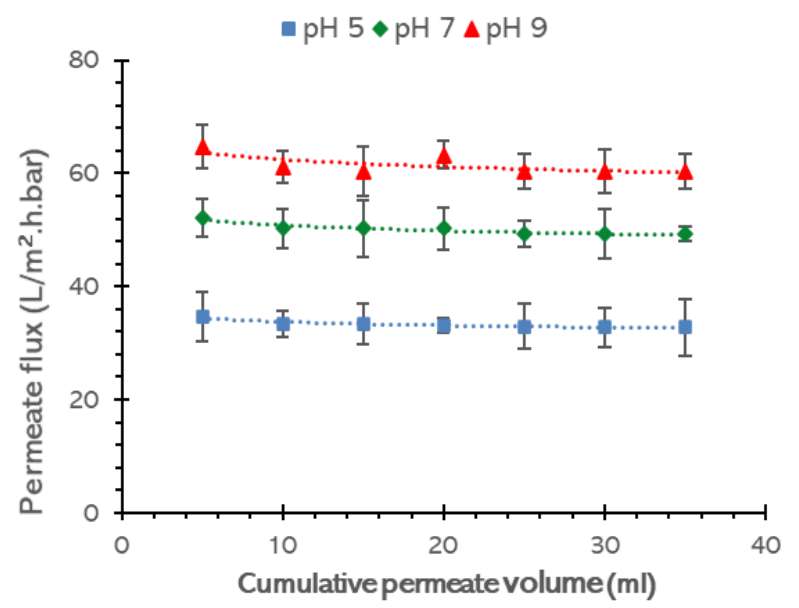

Figure 6. Permeate flux during biocatalysis at different $\mathrm{pH}$ of enzyme immobilization. 
changed to $\mathrm{pH}$ 7. This could lower the electrostatic repulsion between enzyme and membrane at lower $\mathrm{pH}$, hence some part of the enzymes could have leak from the membrane.

\section{Conclusions}

The effect of solution $\mathrm{pH} \mathrm{5,7}$ and 9 during filtration of $\mathrm{ADH}$ enzyme in an attempt to immobilize enzyme in the PES membrane support was investigated upon membrane permeability, enzyme loading and fouling mechanisms. The highest enzyme loading was recorded when immobilization procedure is conducted at $\mathrm{pH} 5$ and the lowest enzyme loading is recorded at $\mathrm{pH}$ 7. The docking mechanism of enzymes on the membrane is due to electrostatic charge and hydrophobic interaction at low $\mathrm{pH}$, while electrostatic repulsion and steric hindrance mechanisms, dominated enzyme retention at high $\mathrm{pH}$. It was observed that, reversible fouling mechanism (intermediate and complete blocking) occurs at $\mathrm{pH} 5$ (intermediate blocking) and 9 (complete blocking). Meanwhile, irreversible fouling, indicated by standard blocking at $\mathrm{pH} 7$ could indicate the most suitable fouling mechanisms to dock the ADH enzyme on the membrane surface. The enzyme is 'protected' inside the membrane pores and could lead to enzyme stability in longer run. The biocatalytic conversion of the reactor reached more than $90 \%$ with a slight decrease of conversion at $\mathrm{pH} 9$ towards the end of the reaction.

\section{Acknowledgment}

The study was funded by the Ministry of Higher Education Malaysia, under Fundamental Research Grant Scheme (FRGS/1/2018/TK10/UITM/03/7).

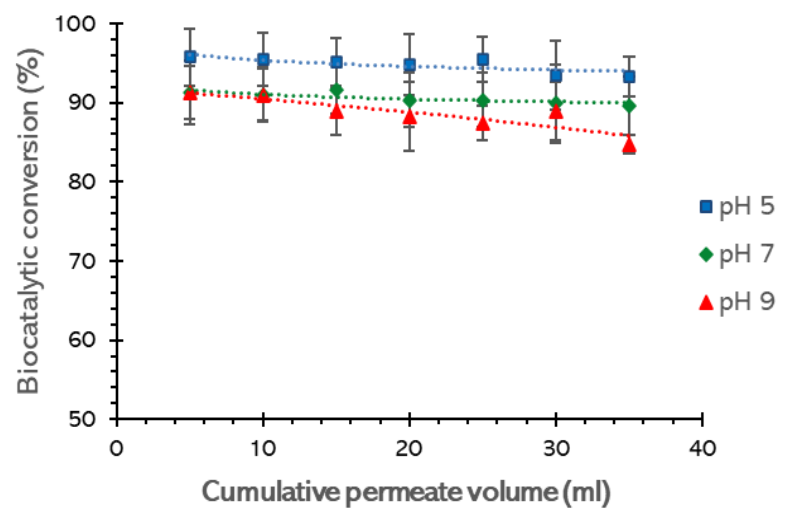

Figure 7. Biocatalytic conversion of formaldehyde to methanol at different $\mathrm{pH}$ of enzyme immobilization.

\section{References}

[1] Myles, A., Babiker, M., Chen, Y., de Conink, H., Connors, S., van Diemen, R., Dube, O. P. (2018). IPCC, 2018: Summary for Policymakers. In V. Masson-Delmotte, H. Pörtner, J. Skea, P. Zhai, D. Roberts, P. R. Shukla, A. Pirani, W. Moufouma-Okia, C. Péan, R. Pidcock, S. Connors, J. B. R. Matthews, Y. Chen, X. Zhou, M. I. Gomis, G. Lonnoy, T. Maycock, M. Tignor, T. Waterfield (Editors), Global Warming of $1.5^{\circ} \mathrm{C}$. An IPCC Special Report on the Impacts of Global Warming of $1.5^{\circ} \mathrm{C}$ Above pre-industrial Levels and Related Global Greenhouse Gas Emission Pathways, in the Context of Strengthening the Global Response to the Threat of Climate Change. https://report.ipcc.ch/sr15/pdf/sr15_spm_final. pdf\%0Ahttp://www.ipcc.ch/report/sr15/

[2] Fischedick, M., Roy, J., Abdel-Aziz, A., A., A., Allwood, J. M., Ceron, J., Geng, Y., Kheshgi, H., Lanza, A., Perczyk, D., Price, L., Santalla, E., Sheinbaum, C., Tanaka, K. (2014). Industry. In T.Z. and J.C.M. Edenhofer, O., R. Pichs-Madruga, Y. Sokona, E. Farahani, S. Kadner, K. Seyboth, A. Adler, I. Baum, S. Brunner, P. Eickemeier, B. Kriemann, J. Savolainen, S. Schlömer, C. von Stechow (Editors) Climate Change 2014: Mitigation of Climate Change. Contribution of Working Group III to the Fifth Assessment Report of the Intergovernmental Panel on Climate Change. Cambridge University Press. DOI: 10.7312/beik90104-006

[3] Gale, J., Bradshaw, J., Chen, Z., Garg, Z., Gomez, D., Rogner, H., Simbeck, D., Willians, R., Toth, F., van Vuuren, D. (2018). Sources of $\mathrm{CO}_{2}$. In I. El Gizouli, J.F. Hake (Editors), IPCC Special Report on Carbon dioxide Capture and Storage. DOI: 10.1007/978-3-03027103-9_8

[4] Yuan, Z., Eden, M. R., Gani, R. (2016). Toward the development and deployment of large-scale carbon dioxide capture and conversion processes. Industrial and Engineering Chemistry Research, 55(12), 3383-3419. DOI: 10.1021/acs.iecr.5b03277

[5] Tollefson, J. (2017). $\mathrm{CO}_{2}$ emissions set to spike in 2017. Nature, 551(7680), 283-283. DOI: $10.1038 /$ nature.2017.22995

[6] Admiraal, A., Elzen, M.D., Roelfsema, M., Soest, H. (2015). Assessing Intended Nationally Determined Contributions to the Paris Climate Agreement. In PBL Netherlands Environmental Assessment Agency. https://www.pbl.nl/sites/default/files/cms/publ icaties/pbl-2015-assessing - intended nationally-determined-contributions-to-theparis-climate-agreement_1879.pdf 
[7] Gadikota, G. (2021). Carbon mineralization pathways for carbon capture, storage and utilization. Communications Chemistry, 4(1), 15. DOI: 10.1038/s42004-021-00461-x

[8] Cuéllar-Franca, R.M., Azapagic, A. (2015). Carbon capture, storage and utilisation technologies: A critical analysis and comparison of their life cycle environmental impacts. Journal of $\mathrm{CO}_{2}$ Utilization, 9, 82-102. DOI: 10.1016/j.jcou.2014.12.001

[9] Boot-Handford, M.E., Abanades, J.C., Anthony, E.J., Blunt, M.J., Brandani, S., Mac Dowell, N., Fernández, J.R., Ferrari, M.C., Gross, R., Hallett, J.P., Haszeldine, R.S., Heptonstall, P., Lyngfelt, A., Makuch, Z., Mangano, E., Porter, R.T.J., Pourkashanian, M., Rochelle, G.T., Shah, N., Yao, J.G., Fennell, P. S. (2014). Carbon capture and storage update. Energy and Environmental Science, 7(1), 130189. DOI: $10.1039 / \mathrm{c} 3 \mathrm{ee} 42350 \mathrm{f}$

[10] Xu, L., Xiu, Y., Liu, F., Liang, Y., Wang, S. (2020). Research progress in conversion of $\mathrm{CO}_{2}$ to valuable fuels. Molecules, 25(16), 3653. DOI: $10.3390 /$ molecules25163653

[11] Zheng, Y., Zhang, W., Li, Y., Chen, J., Yu, B., Wang, J., Zhang, L., Zhang, J. (2017). Energy related $\mathrm{CO}_{2}$ conversion and utilization: Advanced materials/nanomaterials, reaction mechanisms and technologies. Nano Energy, $40, \quad 512-539 . \quad$ D O I : 10.1016/j.nanoen.2017.08.049

[12] Marpani, F., Pinelo, M., Meyer, A.S. (2017). Enzymatic conversion of $\mathrm{CO}_{2}$ to $\mathrm{CH}_{3} \mathrm{OH}$ via reverse dehydrogenase cascade biocatalysis: Quantitative comparison of efficiencies of immobilized enzyme systems. Biochemical Engineering Journal, 127, 217-228. DOI: 10.1016/j.bej.2017.08.011

[13] Obert, R., Dave, B.C. (1999). Enzymatic conversion of carbon dioxide to methanol: Enhanced methanol production in silica sol-gel matrices. JACS - Journal of the American Chemical Society, 121(51), 12192-12193. DOI: 10.1021/ja991899r

[14] Ismail, F.H., Marpani, F., Othman, N.H., Nik Him, N.R. (2021). Simultaneous separation and biocatalytic conversion of formaldehyde to methanol in enzymatic membrane reactor. Chemical Engineering Communications, $208(5), \quad 636-645$. D O I : $10.1080 / 00986445.2019 .1705795$

[15] Luo, J., Marpani, F., Brites, R., Frederiksen, L., Meyer, A.S., Jonsson, G., Pinelo, M. (2014). Directing filtration to optimize enzyme immobilization in reactive membranes. Journal of Membrane Science, 459, 1-11. DOI: 10.1016/j.memsci.2014.01.065
[16] Schafer, A.I., Semiao, A.J.C. (2013). Removal of adsorbing estrogenic micropollutants by nanofiltration membranes. Part A - Experimental evidence. Journal of Membrane Science, $431, \quad 244-256$. D O I : 10.1016/j.memsci.2012.11.080

[17] Jochems, P., Satyawali, Y., Diels, L., Dejonghe, W. (2011). Enzyme immobilization on/in polymeric membranes: Status, challenges and perspectives in biocatalytic membrane reactors (BMRs). Green Chemistry, 13(7), 1609-1623. DOI: 10.1039/C1GC15178A

[18] Trzaskus, K.W., de Vos, W.M., Kemperman, A., Nijmeijer, K. (2015). Towards controlled fouling and rejection in dead-end microfiltration of nanoparticles - Role of electrostatic interactions. Journal of Membrane Science, $496, \quad 174-184 . \quad$ D O I : 10.1016/j.memsci.2015.06.047

[19] She, Q., Tang, C.Y., Wang, Y.N., Zhang, Z. (2009). The role of hydrodynamic conditions and solution chemistry on protein fouling during ultrafiltration. Desalination, 249(3), 1079-1087. DOI: 10.1016/j.desal.2009.05.015

[20] Luo, J., Wan, Y. (2013). Effects of pH and salt on nanofiltration - a critical review. Journal of Membrane Science, 438, 18-28. DOI: 10.1016/j.memsci.2013.03.029

[21] Nyström, M., Zhu, H. (1997). Characterization of cleaning results using combined flux and streaming potential methods. Journal of Membrane Science, 131(1-2), 195-205. DOI: 10.1016/S0376-7388(97)00053-7

[22] Hadidi, M., Zydney, A.L. (2014). Fouling behavior of zwitterionic membranes: Impact of electrostatic and hydrophobic interactions. Journal of Membrane Science, 452, 97-103. DOI: 10.1016/j.memsci.2013.09.062

[23] Van Voorthuizen, E.M., Ashbolt, N.J., Schäfer, A.I. (2001). Role of hydrophobic and electrostatic interactions for initial enteric virus retention by MF membranes. Journal of Membrane Science, 194, 69-79. DOI: 10.1016/S0376-7388(01)00522-1

[24] Marpani, F., Zulkifli, M.K., Ismail, F.H., Pauzi, S.M. (2019). Immobilization of alcohol dehydrogenase in membrane: Fouling mechanism at different transmembrane pressure. Journal of the Korean Chemical Society, $63(4), \quad 260-265$. D O I : $10.5012 / \mathrm{jkcs.2019.63.4.260}$

[25] Khan, I.A., Lee, Y.S., Kim, J.O. (2020). A comparison of variations in blocking mechanisms of membrane-fouling models for estimating flux during water treatment. Chemosphere, $259, \quad 127328$. DO I : 10.1016/j.chemosphere.2020.127328 
[26] Kirschner, A.Y., Cheng, Y.H., Paul, D.R., Field, R.W., Freeman, B.D. (2019). Fouling mechanisms in constant flux crossflow ultrafiltration. Journal of Membrane Science, 574, 65-75. DOI: 10.1016/j.memsci.2018.12.001

[27] Chang, E.E., Yang, S.Y., Huang, C.P., Liang, C.H., Chiang, P.C. (2011). Assessing the fouling mechanisms of high-pressure nanofiltration membrane using the modified Hermia model and the resistance-in-series model. Separation and Purification Technology. $79(3), \quad 329-336$. D O I : 10.1016/j.seppur.2011.03.017
[28] Marpani, F., Luo, J., Mateiu, R.V., Meyer, A.S., Pinelo, M. (2015). In situ formation of a biocatalytic alginate membrane by enhanced concentration polarization. ACS Applied Materials and Interfaces, 7(32), 17682-17691. DOI: 10.1021/acsami.5b05529 